\title{
The Impact of Economic Pro-Growth Policies on the Current Rise of Millennial Startups in the US
}

\author{
Nikhila Kurri
}

Dallas, Texas

Email-Nikhilak71@gmail.com

\begin{abstract}
In a time of unprecedented growth with respect to startups by millennials, ages 18-30, there are a multitude of government responses that allow such growth to take place in our current economy. This study aims to gain an in-depth understanding of pro-investment and pro-growth economic policies established by the US government from 2015-2019. In which the pro-growth policies are characterized as government implemented policies that reduce barriers, create more capital, and increase investment, used to facilitate a growth in business. The focus will then be directed to which of these has the largest influence on the current rise in millennial startup entrepreneurship. The methodology for this study is a mixed-method and correlational study which utilizes surveys of millennial startup entrepreneurs, national data sets of current business, and economic regulations and growth. Through this research, the perspective of millennials on policies and the growth of new businesses can be examined from the influence of economic pro-growth policies in the U.S.
\end{abstract}

Published by IJRP.ORG. Selection and/or peer-review under responsibility of International Journal of Research Publications (IJRP.ORG) 


\section{Literature Review}

\subsection{Historical Context}

In order to understand why this study analyzes the largest impact of a pro-investment and pro-growth policies influence on the current rise in millennial entrepreneurship within the United States, it is important to look at the existing body of research on the subject. First off, let us understand what it means to be an entrepreneur and establish a startup. The first use of the word entrepreneur by an economist was likely in 1730 by Richard Cantillon, who stated that the “...willingness to bear the personal financial risk of a business venture [was] the defining characteristic of an entrepreneur" (Sobel, n.d.). Later on this characteristic was noticed more frequently in individuals which then led to the definition of an entrepreneur, where according to 20th century economist Joseph Schumpeter, and entrepreneur is someone “...who introduce[s] innovations, new processes to produce either new products or old products in new ways, thereby "disturbing" the usual flow of production" (United States Joint Economic Committee, 2016). With this new idea of entrepreneurship within the US many began to intercorrelate it with the concept of Capitalism as the characteristics of entrepreneurship aligned with that of capitalism, provided by Scottish economist Adam Smith (Price, 2011). Now that entrepreneurship was associated with a capitalist economy like the U.S., many began to see a rise in entrepreneurial growth according to the U.S Bureau of Labor Statistics (BLS) Business Employment Dynamics (BED). Where the period from “...1993 to 2006 was marked by an increase in the number of births and deaths [as] new business establishments entered and old establishments exited the economy in greater numbers...in early 2010 and establishment births have since returned to pre-recession levels" (U.S. Bureau of Labor Statistics, 2016). This represents the concept of increased entrepreneurial activity in the U.S.; however, it was unknown of the specific factor that caused this growth. That is why this study analyzes the specific factor of pro-growth policies and how they influence the rise of entrepreneurship in America.

\subsection{Current Context Analysis}


According to Karen Kerrigan, the President and CEO of The Small Business and Entrepreneurship Council (SBE), "investment, manufacturing employment, worker compensation, and new startups have all risen sharply in the two years since the 2016 election. The SBE council is a 501c(4) advocacy, research and education organization dedicated to protecting small business and promoting entrepreneurship. SBE Council educates elected officials, policymakers, business leaders and the public about key policies that enable business start-up and growth" (SBE Council, n.d.). The bottom-line is that pro-growth policy has produced these solid results and favorable circumstances for more growth" (SBE Council, 2019a). This suggests that there is a current rise in new startups and investment largely in part with the results of the 2016 election. Therefore, claiming that this shift in government, has contributed to the new pro-growth policies that have caused the rise in entrepreneurship currently within America. Kerrigan also claims that based on the Council of Economic Advisors' data "[a]ctions taken by the Administration and Congress to balance federal regulatory activity, streamline red tape, reduce burden and produce smarter regulation has created an enabling environment for investment, entrepreneurship and small business growth" (SBE Council, 2019a). In which the CEA, established in 1946, is a United States agency within the Executive Office of the President that advises the President of the United States on economic policies. This shows us how changes to federal regulations and federal policies can impact and enable business growth as they accommodate business needs. Therefore, building the idea that economic pro-growth policies can have similar impacts to the growth of businesses as they also can create business friendly regulations.

Furthermore, now that we understand that there is a rise in startups and that they are correlated with implemented pro-growth policies, we can look into specific pro-growth policies like the USMCA implemented in 2018 by the U.S. government. Where the USMCA “....will create stability and growth for cross-border commerce with Canada and Mexico..." (SBE Council, 2018). This policy is associated with major changes such as creating strong IP protection, reducing shipping costs, reduces regulations which 
reduces duplicative red tape and costs for small businesses, and facilitates market expansion into Mexico and Canada (SBE Council, 2018). This represents how this pro-growth policy will facilitate the rise of new businesses and individuals within entrepreneurship as it removes many limitations that previously were barriers for many businesses growth and expansion within North America. Another pro-growth policy called the TCJA was also implemented recently in 2017 where it made major changes to "...deductions, depreciation, expensing, tax credits and other tax items that affect businesses" (IRS, 2019). Such changes provided large benefits to many businesses as they were able to keep more of their profits and capital with a lower liability cost from taxes and depreciation, thus allowing for a growth in businesses in the US. Finally, the last progrowth policy that this study will evaluate is the Economic Growth, Regulatory Relief and Consumer Protection Act. In part with the policy being made due to the lack of effectiveness associated with the DoddFrank Act, this policy made major changes with regulatory relief associated with banks, capital formation, mortgage lending, and consumer protection (Getter et al., 2018) This allows many businesses to have access to capital much easier and therefore propelling a growth in new businesses. Even though we now know the impacts of specific pro-growth policies on businesses, we still do not know how effective they are compared to each other and their relation to the rise of businesses.

In terms of addressing what new pro-growth policies need to be implemented by the government in order to continue seeing this rise in entrepreneurship within the United States, we see that "policies must continue to lift government-imposed barriers, and encourage capital formation and investment" (SBE Council, 2019b). And to support this argument, it is includes major factors that policies can address like "[t]ransforming the outdated regulatory system, improving capital access, lowering health coverage costs and increasing choice and competition, global market access and intellectual property protection, [and] additional tax code fixes that focus on simplicity..." (SBE Council, 2019b). These represent some key areas for action 
that will cause the continuation of entrepreneurial growth in the US currently and prompting future progrowth policies.

\subsection{Knowledge Gap Proposal}

Currently we have seen the impacts of pro-growth policies on the rise of entrepreneurship within America, the major impacts specific policies have on businesses and the market, and the areas that need to be addressed in the future for this business growth. However, there is no direct understanding of which progrowth policy has the largest influence on this growth or an understanding of how this factor impacts millennials in startups. Therefore, this study will research upon the rise in millennial entrepreneurs within the US today as well as focusing on a specific pro-growth policy that has had the largest impact on entrepreneurial growth.

\section{Methodology}

As we now know that there is a current growth in the number of millennials entering the startup entrepreneurship field, it calls into question the different factors that are allowing this phenomenon to occur. One of those being legal regulations that are facilitating this growth. The question that the method of my study is set up to answer is which pro-investment and pro-growth economic policy established by the US government, from 2015-2019, has the largest influence on the current rise in millennial startup entrepreneurship within the United States. Using this, I hypothesized that the TCJA pro-growth policy implemented by the United States government in 2019 was the economic pro-growth policy with the largest influence on the current rise in millennial startup entrepreneurship within the US as it changed deductions, depreciation, expensing, tax credits and other tax items that affect businesses. It is important to address the assumptions that I am only focusing on and comparing a select few highly impacting pro-growth policies 
instead off all of the economic pro-growth policies established by the US government from 2015-2019, and that there is a current rise in millennial startup entrepreneurship in the US in my research as this idea is supported by the sources analyzed in the literature review.

\subsection{Mixed Methods Correlational Study}

To better understand the methods of my research study we should begin by defining what mixed methods is and its relation to a correlational study in my research. The mixed-methods approach collects and analyzes both qualitative and quantitative data and therefore provides strengths that offset the weaknesses of both qualitative and quantitative research (Creswell, 2015). A correlational study takes the data provided by a research study and often takes a look at the relationships between the different data sets to come to a conclusion about the research. I used these specific methods for my research because any research done in the business field involves the understanding of a wide range of factors associated with the topic. In which understanding the relevant theory of the field such as a theoretical context like economics evaluates the topic more critically and effectively (Greener, 2008). Therefore, I decided not only to use a mixed methods approach to my research but to also include a correlational study in order to understand this context associated with my topic for a deeper understanding of my research. Using these methods of data collection and data analyses I set up the methods of my research by initially focusing on the data collection process using Mixed Methods in the form of a survey. In order to get responses from my target group, I decided to contact my mentors, Dr.Carraher and Sean Haas regarding the platform in which I would distribute my survey on. Dr.Carraher is a Clinical Professor teaching Organizations and Strategy and International Management at The University of Texas at Dallas. He has an educational background of a BBA, MBA, and PHD in the field of business. Sean Haas is a Student Researcher \& Teaching Assistant at The University of Texas at Dallas. He has an educational background of a B.S. Finance and B.S. Economics. They then suggested that I send them 
my survey, on February 4, 2020, to add as a part of a study regarding High IQ increases in intelligence occurring with 50 UTD students. This study included several different types of surveys that ranged from simple to more complex surveys for the study to test if the participant's, who were UTD students, IQ would increase after each round of surveys. So, in part with the other surveys that were included in the study, my survey was a part of the collection.

Going into the format of my survey, I decided some of the most important aspects of my survey included questions of demographics associated with my participants such as questions of socioeconomic status, political orientation, and perception of economic opportunity in entrepreneurship. This is because these are some of the major factors associated with my topic that needed to be researched in order to have valuable data sets that I could extract qualitative/quantitative data from to have an effective correlational study. With this, I created a simple 10 question survey in which initially I would ask two questions regarding age and whether or not the respondent was in startup entrepreneurship to make sure the respondents were millennials in startup entrepreneurship. In terms of the quantitative/qualitative data from my survey, the qualitative data would be acquired from the responses to a specific economic pro-growth policy that influenced the respondent to believe is the most compelling and aiding in your efforts to start a business, a specific future economic prow-growth policy that would lead to the largest growth in millennial startup entrepreneurship if implemented, and whether the respondent even took these policies into account when implementing or planning their business. The quantitative data collected from the survey would be from the different numbers of respondents for each qualitative question's answer options.

After my survey was sent to Professor Carraher and Sean Haas at the UTD facility on February 12, 2020, there was a specified 2-3 weeks time frame that needed to occur for my survey results to be acquired. However, in the process of collecting my survey data there were issues regarding the timeline of when I 
would receive my data back as the study regarding High IQ increases in intelligence occurring with 50 UTD students was being delayed due to complications and modification to the surveys included in the study. This pushed back the date in which I would receive my data back to now March 7, 2020. But after following up with Sean Haas regarding the status of my survey through email on March 16, 2020, I was informed that due to the COVID-19 pandemic all UTD on campus classes and activities would be suspended initially for 2 weeks which was later extended to suspended all UTD on campus classes and activities for the remainder of the semester. And as a result, I was informed that there was a low probability that I would be receiving my survey data back any time soon. Therefore, since I would not be getting my survey data back in the expected time frame of my research, I decided I would still incorporate my survey into my research study but instead I would incorporate theoretical results. I would be analyzing my theoretical results by comparing the predicted data to my hypotheses in cases that my data did not support my thesis or in the cases where my data did support my thesis. I would then use this to see how this impacts the current field of study and what it means for the new understanding of my study. After analyzing theoretical results from my survey data, I would then do a correlational study behind the relationship between higher respondents of a certain pro-growth policy and it's the ability to create the largest influence on the current rise in millennial startup entrepreneurship within the US. I would also be doing a correlational study with other national scaled data from The World Banks's Doing Business Measuring Business Regulations Data Bank. With these data sets, I would compare the rankings and scores of the 190 industries in the U.S associated with the data sets and compare them with the results of my survey for a holistic review regarding the certain economic pro-growth policy that is allowing for this current rise in millennial startup entrepreneurship in the U.S.

\subsection{Limitations}


In any research study, especially in the economic and business discipline, it is important to address the limitations associated with the methods of a research study including the research process and findings. This is because it can improve the credibility of the statements associated with such debatable fields such as business and economics. The major limitation associated with my research process is the fact that I would not receive back any survey data due to the research interruption. Therefore, my method could not be completed as planned for my research which would have allowed a deeper understanding of my topic compared to the theoretical results. Another major limitation associated with my research process and findings is that since I am only focusing on a select few highly impacting pro-growth policies instead off all of the economic progrowth policies established by the US government from 2015-2019, I will not be able to relate my findings to the comparison of all the other economic pro-growth policies, making my findings only true to a certain extent as it cannot be an absolute finding because I am not testing or comparing all the different economic policies. Therefore, I decided to only focus on the economic pro-growth policies of the USMCA, TCJA, and the Economic Growth, Regulatory Relief and Consumer Protection Act. This is because these policies have been declared by a multitude of sources and platforms to have the biggest impact of business regulation and have been declared to create the largest economic growths, supported by the U.S CEA, and SBE Council (SBE Council, 2019b). And finally, another limitation we can see with the survey, if it were to have been conducted as planned, would be the probability of the UTD students being millennials in startups. As it is not a high probability but they would still be able to provide a millennial perspective on this topic so they would still be valuable participants for my survey study.

\section{Data Findings}

\subsection{Correlational Data}

\section{Figure 1}




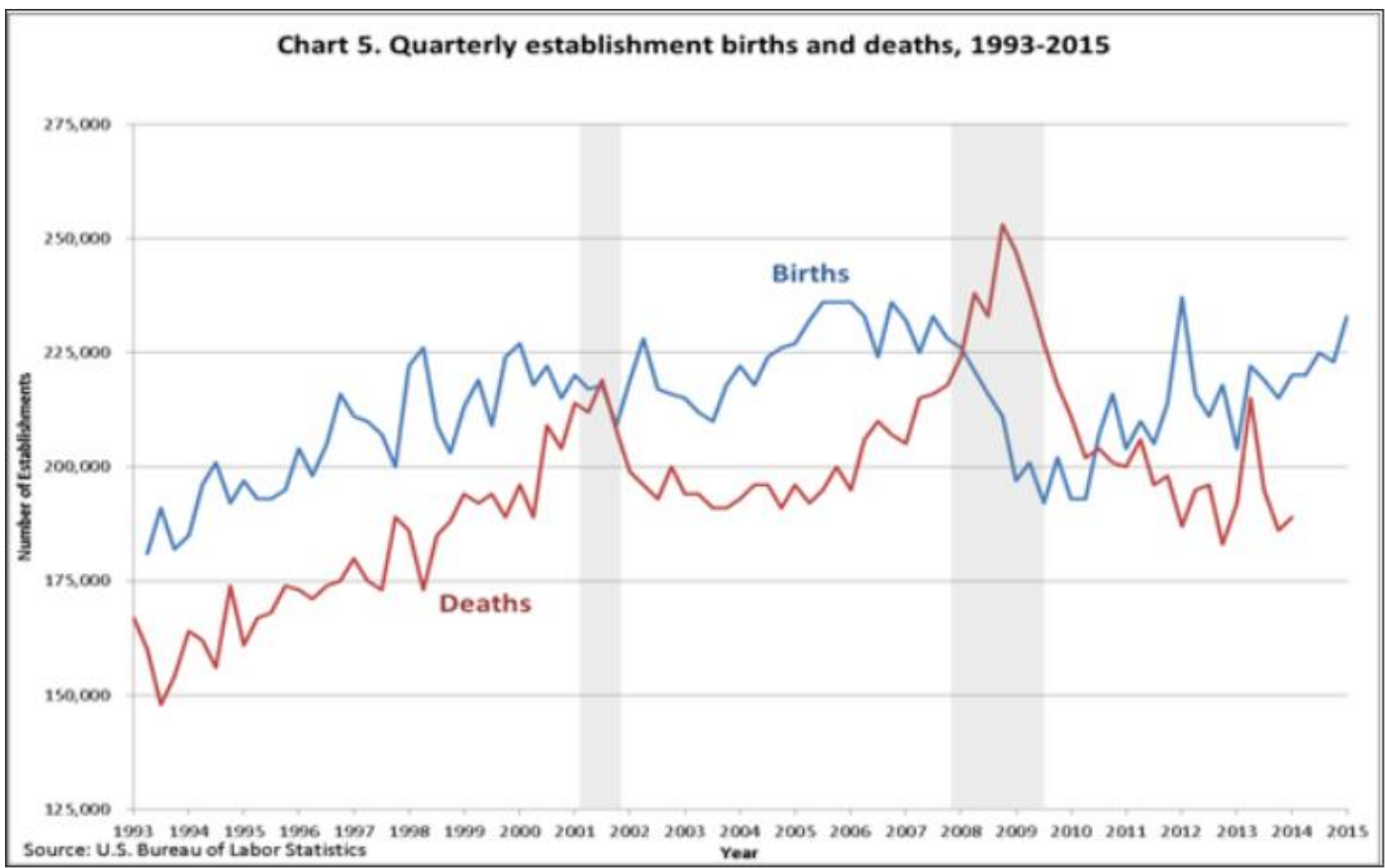

The correlational data of my research starts with the Bureau of Labor Statistics Entrepreneurship and the U.S. Economy Data. Where the Bureau of Labor and Statistics measures labor market activity, working conditions, price changes, and productivity in the U.S. economy to support public and private decision making (U.S Bureau of Labor Statistics, n.d.). This data discusses the quarterly establishment births and deaths of businesses in the U.S from 1993-2015. First off we can see in Figure 1 that from 1993-2006 there was an increase in the numbers of births and deaths of businesses indicating a higher amount of new businesses being established and entering the market as more old businesses exit the market in greater numbers. This period can be therefore marked as having a higher business "churn". However, we can see that at the beginning of December 2007 there was a steep decline in births compared to deaths never seen in the series before. This is largely due to the 2008 recession which was a post-war recession that adversely affected 
every single segment of the U.S economy and resulted in massive job cuts, business closures, and bankruptcies (Fairlie, 2013). However, under the Bush administration at the time, the U.S government was able to release two sets of policy tools to help recover the economy: The Monetary policy and Fiscal Policy. The Monetary policy, exacted by the actions of the Federal Reserve, was used to keep interest rates low and reduce unemployment during and after the recession. The Fiscal policy, enacted by Congress, was then used to establish various forms of government spending and tax cuts. Both sets of policy tools were then used to increase demand, and therefore raised output and more quickly returned the economy to pre-recession conditions. (Diane, 2016). We can then see that the downward trend of births reversed following June 2009 after the recession and the policies used to help the recession were implemented. This shows that business "churn" was then restored to pre-recession levels after the implementation of these pro-growth policies during the recession. This represents how pro-growth policies established by the U.S government have an adverse effect and can propel the growth of businesses which shows how important pro-growth policies are to business sectors and their ability to change the dynamic of the market.

We can then use this idea to address that such policies can also affect the survivability of many companies shown in Figure 2 once again from The Bureau of Labor Statistics Entrepreneurship and the U.S. Economy Data. This chart represents the survival rate of business establishments, by year started and the number of years since establishment, from 1994-2015.

\section{Figure 2}




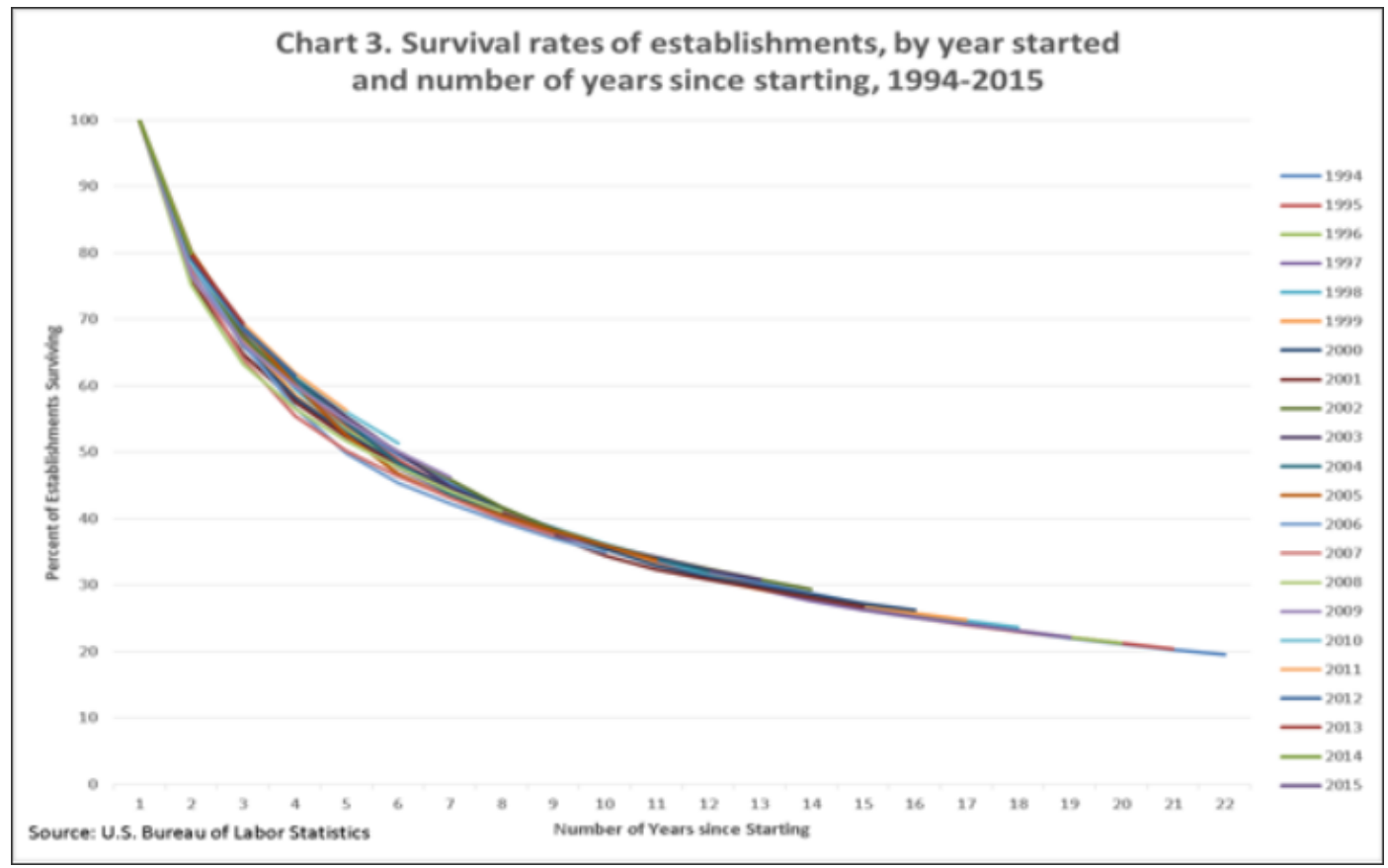

We can see from this graph that the businesses established after the 2008 recession in part with newly implemented 2008-2009 pro-growth policies had a high percentage of businesses established for 1-6 years to survive 100-40\%. And other businesses following in 2012-2015 had larger establishment years ranging from 1-22 and greater variance in survivability with 2014 businesses close to the 100-60\% survivability. This shows that in the more recent years, there is more growth of businesses with survivability and years established. This sets the understanding of pro-growth policies' impact on the current growth of businesses.

One of the data sets that compares the business regulations established by the U.S government and its impact on businesses is the World Bank Doing Business Data. This figure (3) explains the 2020 U.S Business Regulations Ranking in which the ranking of 11 different business regulations in the U.S. compared 
to 190 economies and their ability to foster businesses. These rankings are calculated annually in which the most recent computing was in 2020 . In terms of the scale of the chart, $1=$ most friendly business regulation and the larger the number is the less friendly the regulation is to businesses.

\section{Figure 3}

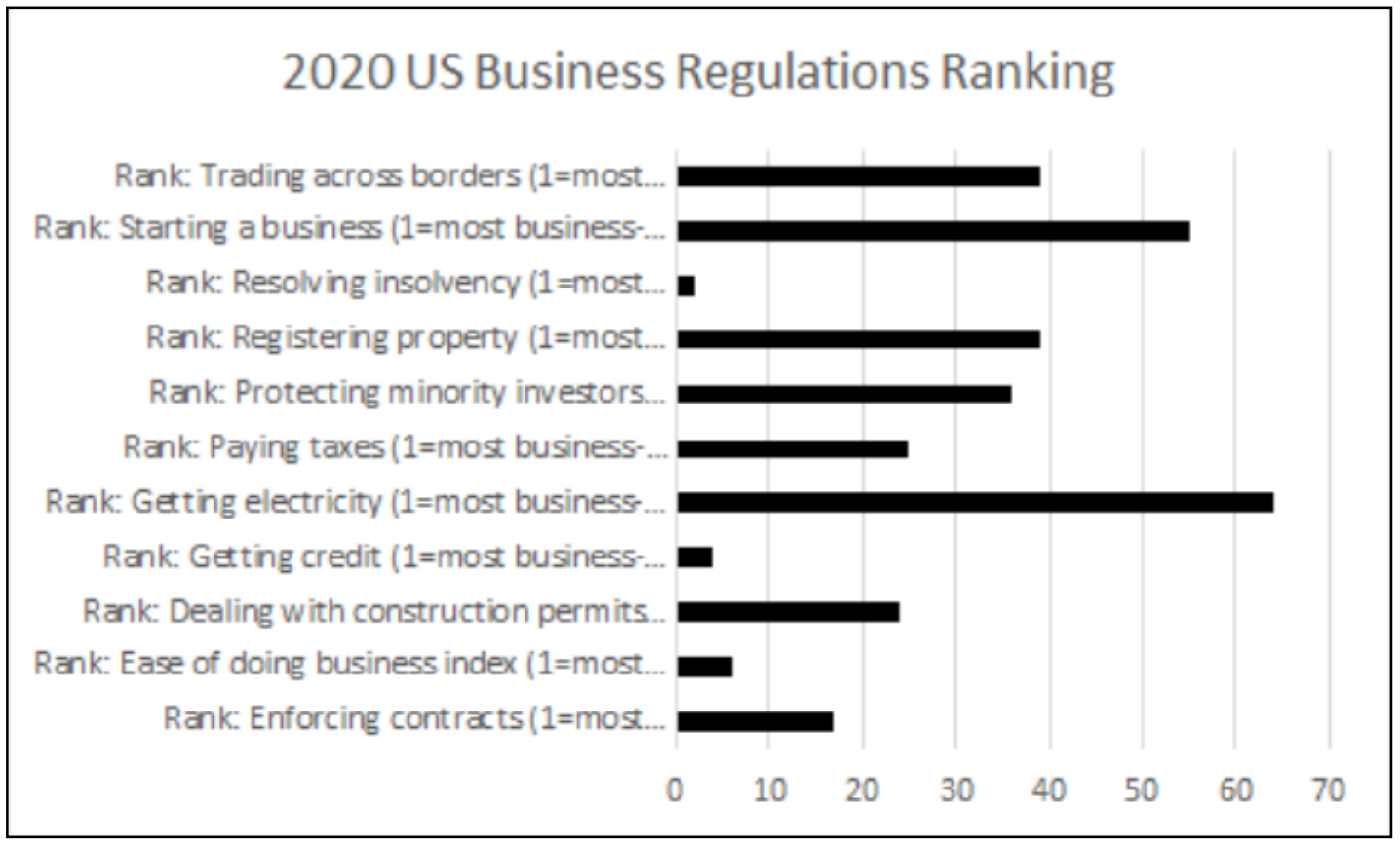

We can see that based on Figure 3 that most business-friendly regulations are resolving insolvency, getting credit, and ease of doing business index, respectively. However, starting a business (ranked 55) and trading across borders (ranked 38) were ranked in the middle in terms of business friendliness. The progrowth policies that largely related to these ideas are the TCJA and the USMCA, but the policy that focused on business regulations, in general, was the Economic Growth, Regulatory Relief and Consumer Protection 
Act. The Tax Cuts and Jobs Act (TCJA) is a pro-growth policy that changed deductions, depreciation, expensing, tax credits and other tax items that affect businesses. It has also helped many entrepreneurs selffinance business expansion, raise employee wages, and offer new benefits (IRS, 2019). While the U.S.Mexico-Canada Agreement (USMCA) is a pro-growth policy that allows for a more stable cross-border and trade economy (SBE Council, 2018). And finally, The Economic Growth, Regulatory Relief and Consumer Protection Act is a pro-growth policy that began to undo the unnecessary regulations placed on smaller, local banks and credit unions under the 2010 Dodd-Frank Act. It allows families and businesses access to credit when they need it and relieves a financial burden (Getter et al., 2020). Therefore, this data set allows for the comparison of the effectiveness of business regulations in the US concerning economic pro-growth policies. It also allows us to see what policies can be implemented in the future to help business growth, trade, etc.

\subsection{Survey Data}

Using the knowledge then presented in these 3 data sets, we can question and set the background for my survey. Initially I predicted that the TCJA will be the policy that has the largest impact on the growth of businesses by millennials. I also predicted that the data would encourage increased access to capital for business growth in the future and that the current U.S economy is growing and enabling business growth. Where increasing access to capital would allow improvements to crowd funding and revisiting the JOBS Act 3.O for capital formation and capital markets modernization (SBE Council, 2019b). If my hypothesis was supported, the main parts of my survey data would have represented a large percent of my participants responding that they believed that the current US economy is growing and that in the future the US economy will continue to grow. They would also respond that the TCJA policy would be the most compelling and aiding policy in their efforts to start a business and that the implementation of an increased access to capital economic pro-growth policy would lead to the largest growth in millennial startup entrepreneurship if 
implemented. However, if my hypothesis were not supported, the main parts of my survey data would be responses that state that the current US economy is stagnant or shrinking and that the US economy in the future would be stagnant or shrinking. Other responses would also include that policies such as the USMCA and the Economic Growth, Regulatory Relief and Consumer Protection Act were the most compelling and aiding in their efforts to start a business. And in terms of the economic pro-growth policy that would lead to the largest growth in millennial startup entrepreneurship if implemented, the responses would state either increasing healthcare affordability, choice, and innovation, regulatory system transformation and reform, or growth via global markets and strengthening IPs. Where increasing healthcare affordability, choice, and innovation would help to improve affordability and choice, such as those made to small business health plans and short-term limited-duration plans (SBE Council, 2019b). Also, where regulatory system transformation and reform would allow key reforms such as cost-benefit analysis, continuous regulatory review, convening small business owners to determine impact, a collaborative and transparent review of a problem (SBE council, 2019b). And finally, the growth via global markets and strengthening IPs would increase trade agreements and deals and creating strong IP protections at home and in international markets (SBE Council, 2019b) Other survey responses related to questions that are not directly correlated to my hypothesis, would be demographic questions and the value of pro-growth policies in our current economy in which the value of these questions is not as significant to my study.

\section{Data Analysis}

\subsection{Implications}

The current possible implications of my data are that the pro-growth policies established by the U.S government can have adverse effects and can propel the growth of businesses. This shows how important progrowth policies are to business sectors and their ability to change the dynamic of the market. Moreover, this 
also relates to how pro-growth policies are increasing the longevity of more businesses and their survivability in markets which helps facilitate more growth in businesses. We can also see from the final data set, the comparison of the effectiveness of business regulations in the US concerning economic pro-growth policies. It allows us to see what policies or regulations that are currently effective in helping or hinder businesses growth. We can then look at policies that can be implemented in the future to help business growth, trade, etc... based on the current regulations effectiveness. This all comes down to the idea that there is a current rise in business establishments supported by mid-level business regulations in the U.S. that are facilitating implementations of economic pro-growth policies for businesses in the U.S. Thus, bringing us to focus on the specific economic pro-growth policies that were based on previous market reactions to mid-level business regulations investigated through my survey. In terms of my survey results, if the data were to support my hypothesis, we would state that the pro-growth policy that had the largest influence on the current rise in millennial startup entrepreneurship, established by the US government from 2015-2019, was the TCJA. Therefore, we can conclude that the current millennials who are going into startup entrepreneurship are heavily inclined by "a rate cut [that] incentivize[s] investment by increasing the after-tax profitability of marginal investment projects, which would then lead to a higher capital stock per worker, higher productivity, and subsequently higher wages" (Mathur, 2020). However, in the case that my data would not support my hypothesis, we would claim that the pro-growth economic policies of the USMCA or the Economic Growth, Regulatory Relief and Consumer Protection Act established by the US government from 2015-2019, had the largest influence on the current rise in millennial startup entrepreneurship. This would show us that the current millennials are inclined by policies that are more sector specific like the USMCA that "noted the biggest gains...are for the manufacturing and the service sector" who gain most secure and less regulating trade restrictions (Guta, 2019). We would also see that the current millennials in startup entrepreneurship find that the key areas that needed reform were associated with mortgage lending, regulatory relief for 
"community" banks, consumer protection, regulatory relief for large banks, and regulatory relief for capital formation represented by the Economic Growth, Regulatory Relief and Consumer Protection Act (Getter et al., 2018). We can also use the data based on the future pro-growth policies that need to be implemented to display the areas of concern current millennials have with the current market that need to be addressed to allow them to future growth their startups. Overall, we can use this data to understand the cause of more Millennials entering the market with new startups because the current policies allow for a business-friendly market.

\subsection{Limitations}

In terms of the limitations of my data, one of the more apparent ones is associated with the lack of actual survey results. Since I was not able to conduct an actual survey and instead focused on theoretical results, there is no definite way to conclude the full new understanding of my study, as there is no direct input from the survey participants. This makes it difficult to understand the full scope of the millennial perspective in terms of the policies that influenced the growth of millennial startups. It also doesn't allow for a definitive data conclusion that can influence the field of study as the data theorizes the preferred policy implications that millennials would lean towards so it is hard to determine which policies should be implemented in the future as a result of these trends. Another lamination of my data, that is more associated with my correlational data, is that the data sets all are studies that are set in different time frames such as 1993-2015, 1994-2015, and 2020 which can make it difficult to compare in one cohesive timeframe. For instance, although the data sets from the U.S Bureau of Labor Statistics are studies previous to the 2015 time frame, it still sets a good foundation of ideas that can be compared to the impact of pro-growth policies from 2015-2019. This also relates to the 2020 Business Regulation Rankings which differs from the 2015-2019 time frame set for the pro-growth policies in the study. However, this data set will allow us to compare the effectiveness of the 
2015-2019 policies in the future for businesses which will allow us to have a more comparative analysis of the policies' effectiveness. Therefore, even though the time frames of the comparative data differ with the 20152019 time frame of the pro-growth policies focused on in the study, this will allow us to better establish a foundation and comparative analysis of the impact pro-growth policies have on the current growth of startups by Millennials. And finally, one of the more difficult issues for future studies would be finding many peer reviewed academic sources to support the background and understanding of this topic as it is a fairly new research topic. And since policies are constantly being added and changed throughout time so the comparison of policies effectiveness will only last for a certain timeframe.

\section{Conclusion}

\subsection{Impact to Current Economy}

Through this study, we are able to analyze the impact of pro-growth policies in reference to the growth of millennial startups which will allow the current field of economics and business regulations to gain a new perspective into the effectiveness of current economic pro-growth policies. In terms of the current climate of our economy, we can use this study to understand which factors have the heaviest influence on the stability and growth of many businesses during a shift in the economy. Currently we are experiencing a large shift in our economy due to the COVID-19 pandemic where Jesse Rothstein, director of Berkeley's Institute for Research on Labor and Employment (IRLE), suggests that our current economy is “...definitely headed to something much deeper than the Great Recession, and comparable to Great Depression in depth" (Lempinen, 2020). With the current conditions of our economy resembling a recession this is causing businesses throughout the US to face issues such as shutdowns, lack of access to capital, lack of profitability, and massive layoffs (U.S. Chamber of Commerce, 2020). This can then be used to assess the need for government pro-growth policies to help businesses in the current economy. These pro-growth policies can include ones 
that help secure liquidity such as the proposed Small Business Workforce Stabilization Fund that "would provide immediate cash flow to the most vulnerable businesses, keep employees on payroll, and allow businesses to grow once customers return. The legislation would also increase the loan limit for SBA Express from \$350,000 to \$1 million” (Monson, 2020). Where the SBA is the Small Business Administration of the U.S. federal government. Or other pro-growth policies that would allow businesses to cover payroll and employee expenses would include the Restoring Economic Security, Confidence, and User Endurance (RESCUE) Businesses Act in which the "SBA would waive all fees for all 7(a) loans for one year for both lenders and borrowers and provide a 90 percent loan guarantee for all loans..." as well as an increased "loan limit for SBA Express from $\$ 350,000$ to $\$ 1$ million” (Monson, 2020). This allows us to see how instrumental economic pro-growth policies established by the U.S. government are for a change in businesses' survivability.

\subsection{Future Studies}

Based on this study, since we had theoretical results for the survey data that provided the millennial perspective associated with the effectiveness of the pro-growth policies on the rise of millennial startups in the U.S., this would allow future studies to proceed to replicate the parameters and format of this study's survey to find the definitive policy that has the largest impact of the rise of millennial startups. Another direction of study that can be done based on this paper could be by changing the parameters of the study from a U.S. perspective to another country or to a much smaller region like a state. Other changes to the parameter could be a specific industry study where they can analyze the effectiveness of pro-growth policies on businesses comprising a specific sector such as technology, fashion, investment, etc. industries.

Overall through this study we determined that through mid-level regulations and pro-growth policies, established in the U.S. from 2015-2019, such as the TCJA, USMCA, and the Economic Growth, Regulatory 
Relief and Consumer Protection Act, we can see that all of these factors have an impact on the rise in millennial startups in the US.

\section{Acknowledgements}

This work would not have been possible without the efforts of many individuals that have guided me throughout this research process.

I would like to express my gratitude to my mentors Dr.Carraher and Sean Haas who have equipped me with knowledge in my field of study and aided me with different opportunities in my research.

I would also like to thank Mr.Catrette, my AP Research teacher, for assisting me through the different parts of the research process and giving me guidance in any research interruption I faced. 


\section{References}

Creswell, J. W. (2015). A concise introduction to mixed methods research. Thousand Oaks: SAGE.

Diane Whitmore Schanzenbach, a. (2016). Nine facts about the Great Recession and tools for fighting the next downturn. Retrieved 23 March 2020, from https://www.brookings.edu/research/nine-factsabout-the-great-recession-and-tools-for-fighting-the-next-downturn/ Doing Business. (2020). Retrieved 23 March 2020, from https://www.doingbusiness.org/

Fairlie, R. W. (2013, April 4). Entrepreneurship, Economic Conditions, and the Great Recession. Retrieved February 19, 2020, from https://doi.org/10.1111/jems.12017

Getter , D. E., Labonate, M., Shorter , G., Su, E., Weiss, E., \& Perkins, D. W. (2018, June 6). Economic Growth, Regulatory Relief, and Consumer Protection Act (P.L. 115-174) and Selected Policy Issues. Retrieved January 23, 2020, from https://fas.org/sgp/crs/misc/R45073.pdf

Greener, S. (2008). Business research methods. Place of publication not identified: BookBoon.

Guta, M. (2019, May 22). Small Business Trends: New Data Suggests Small Businesses Are Winners in USMCA Deal. Retrieved May 22, 2020, from https://ustr.gov/trade-agreements/free-tradeagreements/united-states-mexico-canada-agreement/what-they-are-saying/small-business-trends 
Internal Revenue Service (IRS). (2019, December 31). Tax Cuts and Jobs Act: A comparison for businesses. Retrieved February 17, 2020, from https://www.irs.gov/newsroom/tax-cuts-and-jobs-act-acomparison-for-businesses

Lempinen, E. (2020, April 10). COVID-19: Economic impact, human solutions. Retrieved April 23, 2020, from https://news.berkeley.edu/2020/04/10/covid-19-economic-impact-human-solutions/

Mathur, A. (2020, February 24). Let The Dust Settle On The TCJA Before Judging Its Effectiveness. Retrieved March 19, 2020, from https://www.taxpolicycenter.org/taxvox/let-dust-settle-tcja-judgingits-effectiveness

Monson, C. (2020, March 27). What Small Businesses Need to Survive the Coronavirus Crisis. Retrieved May 5, 2020, from https://hbr.org/2020/03/what-small-businesses-need-to-survive-the-coronaviruscrisis

Price, R. (2011). What is the history of entrepreneurship?. Global Entrepreneurship Institute. Retrieved 16 October 2019, from https://news.gcase.org/2011/02/04/what-is-the-history-of-entrepreneurship/

SBE Council. (n.d.). About Us. Retrieved October 29, 2019, from https://sbecouncil.org/about-us/ 
SBE Council. (2018, November 30). Advocate for Entrepreneurs and Small Businesses Applauds Signing of USMCA. Retrieved October 16, 2019, from https://sbecouncil.org/2018/11/30/advocate-forentrepreneurs-and-small-businesses-applauds-signing-of-usmca/

SBE Council. (2019a, March 22). Good News for Entrepreneurs in the "2019 Economic Report of the President". Retrieved October 16, 2019, from https://sbecouncil.org/2019/03/22/good-news-forentrepreneurs-and-startups-in-the-2019-economic-report-of-the-president/

SBE Council. (2019b, January 15). The 2019 Policy Agenda for Entrepreneurs and Small Business. Retrieved October 16, 2019, from https://sbecouncil.org/2019/01/15/the-2019-policy-agenda-for-entrepreneursand-small-business/

Sobel, R. S. (n.d.). Entrepreneurship. Retrieved November 13, 2020, from https://www.econlib.org/library/Enc/Entrepreneurship.html

United States Joint Economic Committee. (2016, July 20). The State of Entrepreneurship. Retrieved October 16, 2019, from https://www.jec.senate.gov/public/index.cfm/republicans/2016/7/the-state-ofentrepreneurship

U.S. Bureau of Labor Statistics. (n.d.). What We Do. Retrieved from https://www.bls.gov/bls/infohome.htm

U.S. Bureau of Labor Statistics. (2016, April 28). Business establishment age. Retrieved October 16, 2019, from https://www.bls.gov/bdm/entrepreneurship/entrepreneurship.htm 
U.S. Chamber of Commerce. (2020, May 5). Small business coronavirus impact poll. Retrieved May 20,

2020, from https://www.uschamber.com/report/small-business-coronavirus-impact-poll 